\title{
John the purifier: His immersion and his death
}

\author{
Bruce Chilton $^{1}$ \\ Bard College, Annadale-on-Hudson, New York \\ Visiting Professor: University of Pretoria
}

\begin{abstract}
This article aims at arguing that John the Baptist's role in the Synoptic Gospels is both catechetical and christological. John points the way forward to believers' baptism after the manner of Jesus. John's preaching of repentance in $Q$ is cast within the needs of Christian catechesis and addressed to hearers who are at the margins of Judaism. Likewise, the advice to relative prosperous converts in Luke 3:10-14 is not part of the historical John's message. In evaluating John the Baptist one should not consider his allegedly prophetic status but the fact that he immersed people and purified them..
\end{abstract}

\section{INTRODUCTION}

Discussion within "the Jesus Seminar" brought me to make a suggestion which at the time seemed radical to some of my colleagues. Our point of departure in evaluating John the Baptist should not be his allegedly prophetic status (attributed to him in the Synoptic tradition), but the fact that he immersed people for the simple purpose of purification. That orientation was later developed further in several books and articles, and has been taken up most fully by Joan Taylor in her recent study of John. ${ }^{2}$ Those contributions fashion a fresh perspective on John, which in turn influences our picture of Jesus

\footnotetext{
1 Prof Bruce Chilton visited the University of Pretoria as research fellow of Prof Dr Andries G van Aarde, July-August 1999.

2 See Chilton, B Judaic Approaches to the Gospels (International Studies in Formative Christianity and Judaism 2) (Atlanta: Scholars Press, 1994) 1-37; "Yochanan the Purifier and His Immersion," Toronto Journal of Theology 14.2 (1998) 197-212; Jesus' Baptism and Jesus' Healing: His Personal Practice of Spirituality (Harrisburg: Trinity Press International, 1998); Taylor, J, The Immerser: John the Baptist within Second Temple Judaism (Grand Rapids and Cambridge: Eerdmans, 1997).
} 
profoundly. At the time of my initial paper, however, the idiom of discussion was a sustained critique of Robert Webb's point of view, and I hope the reader will appreciate that the concern was then (and now is) to re-orient our critical perspective, rather than to single out Webb's study for criticism.

The decision to free John from the apologetic and catechetical aims of the Synoptics in regard to his purpose has also prompted a vigorous reconsideration of his chronology (and particularly, the time of his death). The conflation of the major events of Jesus' life, including the death of John, into a single year served the purpose of introducing Christian initiates into the basics of their faith within an easily followed, annual curriculum, but it makes for implausible history to follow the Synoptic calendar as if it provided a reliable chronicle of those events. Once John is placed in his historical context, the depth of his influence upon Jesus becomes apparent.

\section{THE PURPOSE OF JOHN'S IMMERSION}

Robert Webb's recent book, John the Baptizer and Prophet, may be thought of as a reasonable statement of a long-established consensus regarding John. He is portrayed as a "popular prophet," by which it is meant that John set out to behave as did the leaders whom Josephus styles "false prophets:" convinced he was leading Israel into the final, messianic judgment, John called the people to "repentance baptism," that is to a "conversionary repentance" of which his own ministry was the symbol. ${ }^{3}$ Webb's John is the lineal descendant of Wink's characterization of him as "the frontier character of the Christian proclamation," and more generally of the prophetic representations of John which have dominated the secondary literature. ${ }^{4}$

The irony of the allegedly critical consensus which has emerged is that it so neatly confirms the evaluation of John in the Gospels' presentation. Scholars who by training

\footnotetext{
${ }^{3}$ Robert Webb, John the Baptizer and Prophet: A Socio-Historical Study (Journal for the Study of the New Testament Supplement Series 65) (Sheffield: Sheffield Academic Press, 1991), 214, 215.

4 See Walter Wink, John the Baptist in the Gospel Tradition (Society of New Testament Studies Monograph Series 7) (Cambridge: Cambridge University Press, 1968). As Wink's title suggests, he appropriately focuses on what the tradition makes of John. Unfortunately, his work has sometimes been taken up as if it intended an historical description. For a discussion of the literature see also Jean Steinmann (tr. M. Boyes), John the Baptist and the Desert Tradition (Harper: New York, 1958); Charles H H Scobie, John the Baptist (Fortress:Philadelphia, 1964); Ernst Bammel, "The Baptist in Early Christian Tradition," New Testament Studies 18 (1971-1972) 95-128, in addition to Taylor.
} 
and habit dispute whether Jesus really compared John to the messenger of Malachi (that is, to Elijah), which is the identification ascribed to Jesus in the sayings' source (Matthew 11:7-19/Luke 7:24-35), are, apparently, for some reason more willing to accept that John actually was such a figure. The same romanticism which makes John a more vivid figure than Jesus in Rembrandt, Kazantzakis, and "Godspell," makes him a more historical figure than Jesus in much contemporary scholarship, despite the complete lack of evidence deriving directly from John's own movement. Ed Sanders, for example, takes it as the first among "[t]he almost indisputable facts" regarding Jesus that he "was baptized by John the Baptist," and then accepts at face value the attribution in the Gospels to John of a preaching of eschatological repentance. Sanders even maintains that he is sufficiently informed regarding John's position that he can characterize Jesus as relatively deemphasizing the importance of repentance as compared to John. ${ }^{5}$

Before scholars who think of themselves as critical accept the historical reliability of the Gospels' portraits of a prophetic John, certain cautions are in order. In the first place, whether or not Jesus compared John to Elijah, it is evident that the christology of "Q" has an interest in the comparison. Within " $Q$," Malachi is cited after the presentation of John's question from prison, whether Jesus is "the one who is coming" (Matthew 11:26/Luke 7:18-23). As followed by Jesus' citation of Malachi (Matthew 11:7-19/Luke 7:24-35), "the one who is coming" appears to be a messianic title, but it is of far less precise meaning, taken on its own terms or within the context of John's question from prison (even assuming the term itself reflects John's interest). ${ }^{6}$ Moreover, the "citation" from Malachi has been distorted in a messianic direction;" the messenger is sent "before you," rather than "before me." It cannot be argued that the identification of John with the messenger from Malachi is anything but tendentious, and applied in the service of an exaltation of Jesus' status within "Q," whatever the origin of that identification.

\footnotetext{
5 E P Sanders, Jesus and Judaism (Philadelphia: Fortress, 1985), 11, 108-9, 227. For a criticism of Sanders's position in the last regard, see Chilton, "Jesus and the Repentance of E P Sanders," Tyndale Bulletin 39 (1988) 1-18.

- See John S Kloppenborg, The Formation of Q: Trajectories in Ancient Wisdom Collections (Philadelphia: Fortress, 1987), 104-5, 107-8.

7 See Joseph A Fitzmyer, The Gospel According to Luke (I-IX): The Anchor Bible (Garden City: Doubleday, 1981), 672 .
} 
The identification of John as Elijah by means of Malachi 3 (suitably distorted) is also represented within Markan tradition specifically (1:2), where an "overlapping" with "Q" is to be explained. Streeter makes the telling comment that "the overlapping of Mark and $\mathrm{Q}$ is more certain than the existence of Q." ${ }^{\prime 8}$ The problem so vexed Streeter that he changed his mind on the subject over the years. Earlier, he had come quite firmly to the conclusion that Mark knew the source in writing, and even that Mark "wrote to supplement Q." By 1924, however, when Streeter came to write his classic contribution to the study of the Synoptics, he considered that Mark was "taken down from rapid dictation by word of mouth," 10 so that he viewed the relationship between Mark and Q as more attenuated than he had earlier argued. Now he is not certain $Q$ was a written document, and disowns attempts to specify its contents. " What intervened between 1911 and 1924 to alter Streeter's approach was his work with A J Appansamy (published in 1921) on the Indian mystic, Sadhu Sundar Singh. ${ }^{12}$ That research brought Streeter face to face with the overlapping of written and oral sources within cycles of tradition, and he consciously attempted to account for such phenomena within his work on the Synoptics. ${ }^{13}$

The problem of "overlapping" only remains for Streeter, and for his followers, because two features of " $Q$ " which he postulated within the argument of 1911 are imported into the very different analysis of 1924. If one follows Streeter's later formulation, there is no reason to assume that $Q$ is an early, written product of a Galilean phase of the movement. Indeed, its production in Syria is betrayed by its assumption of a missionary setting within which Judaism is more marginal and there is an established community of eschatologically fervent Christians. ${ }^{14}$ That setting, in turn, assumes that an apostolic gospel has already been preached and heard, a gospel which commenced with

\footnotetext{
${ }^{8}$ Burnett Hillman Streeter, The Four Gospels: A Study of Origins (London: Macmillan, 1924), 186.

9 Cf his contribution to William Sanday (ed.), Studies in the Synoptic Problem (Oxford: 1911), 165-66, 176-77, 219.

${ }^{10}$ Streeter, B H, 163.

1 Streeter, B H, 184-5 187, 237, 239-242.

12 The Sadhu: A Study in Mysticism and Practical Religion (London: Macmillan, 1921).

${ }^{13}$ Streeter, B H, 192-195.

${ }^{14}$ See Siegfried Schulz, Q: Die Spruchquelle der Evangelisten (Zürich: Theologischer Verlag, 1972).
} 
the preaching of John (cf Acts 10:34-43, and the reference to the spirit in vv 44-48) as typologically related to that of Jesus. In short, there is no reason, on the formulation of the later Streeter, to assume that the source was a primitive, written "Q," or that knowledge of that "document" must be attributed to "Mark" (as if the text were a person). A Syrian setting of the material in " $Q$ " (whether or not a document, whatever we might mean by "document') would also account for the use of the material in Antioch (within Luke) and Damascus (within Matthew) especially, and for its eventual mutation into an aphoristic form in Edessa (within Thomas). The relative non-appearance of "Q" in Mark is also more easily understood on the supposition of Q's Syrian provenience, and "overlapping" is a natural feature, if Mark is a later representation of the sort of apostolic gospel which the mishnaic source we call "Q" supplements.

Whatever is made of the "overlapping" with "Q," Mark proceeds to cohere with the triple tradition as a whole in offering a citation of Isaiah 40 and a portrayal of John as a prophet in the wilderness (Matthew 3:1-6/Mark 1:4-6 cf Luke 3:4-6). The point of John's preaching is of the one who is stronger than he, whose baptism of judgment is to follow John's baptism with water (Matthew 3:11; Mark 1:7, 8; Luke 3:16). When the scene in which Jesus is baptized follows (Matthew 3:13-17; Mark 1:9-11; Luke 3:21, 22), there can be no doubt but that he fulfills John's reference to a figure greater than he. But it is equally plain that the pointing of John's preaching and activity towards Jesus is achieved by a shaping of its contextual presentation at the very least, and the probability is high that the conviction that John was a messianic messenger in the manner of Malachi 3 and Isaiah 40 distorted whatever meaning he and his followers originally attached to what he did and said. John 1:21 may just preserve an awareness of such distortion, by presenting the baptist as denying he is Elijah or "the prophet."

John the Baptist's role in the Synoptic Gospels, then, is both catechetical and christological. He points the way forward to believers' baptism after the manner of Jesus, who is greater than John. That is the case both in the apostolic catechesis of the triple tradition which conveys the scene of Jesus' own baptism in association with John's movement, and in the assertion in the sayings' source that the least in the kingdom is greater than John the Baptist (Matthew 11:11b; Luke 7:28b). John's preaching of repentance in the mishnaic source conventionally known as " $Q$ " is replete with warnings 
and encouragements for potential converts: Jewish opponents are a brood of vipers (Matthew 3:7; Luke 3:7), what matters is producing fruits worthy of repentance rather than genetic kinship with Abraham (Matthew 3:8, 9; Luke 3:8), and the urgency of the imperative to repent is as keen as an ax laid at the root of a tree (Matthew 3:10; Luke 3:9). Whatever may or may not be reflected of John's preaching here, it is evidently cast within the needs of Christian catechesis ${ }^{15}$ and addressed to sympathetic hearers who are assumed to be at the margins of Judaism. Likewise, the advice to relatively prosperous converts in Luke 3:10-14 - presumably from the Lukan version of " $Q$ " - is redolent of a social setting more reminiscent of Lukan Antioch than of the Baptist's Peraea: charitable giving by revenue contractors and Roman soldiers is not likely to have been the burden of the historical John's message. ${ }^{16}$

That John should be taken as a prophet within the Gospels, then, is entirely natural. It permits him to be seen as a prototype of Christian teachers who were also seen as prophets. But the more natural it is within evangelical preaching to portray John as a prophet, the less reasonable it is to claim that that is what he was within his own estimate or his sympathizers. Webb nonetheless considers the category of prophet alone as suitable for understanding John: his only indecision is whether John was a "clerical prophet," a "sapiential prophet," an oxymoronic "solitary popular prophet," or a "leadership popular prophet."

Such subdivisions are alleged to derive from Josephus, but that derivation is only possible by means of tendentious exegesis. What is a "sapiential prophet" but a sage? Josephus indeed describes Essenes who foretell the future, and whose wisdom derives from study and purification (Jewish War II $\S 159$ ). John may have been comparable to them in some. ways, but that does not make him or them prophetic by pretension. It is to

\footnotetext{
15 The similarily of sayings ascribed to Jesus is striking, although infrequently considered; $c f$. Matthew 3:10 with 7:19; $3: 12$ with 13:30; $3: 7$ with 12:34 and Chilton, B, God in Strength: Jesus ' Announcement of the Kingdom (Studien zum Neuen Testament und seiner Umwelt 1) (Freistadt: Plöchl, 1979; reprinted in "The Biblical Seminar" of Sheffield: JSOT, 1987), 188.

${ }^{16}$ See Fritz Herrenbrück, Jesus und die Zollner: Histortsche und neutestamentlich-exegetische Untersuchungen (WUNT 2/41) (Tübingen: Mohr-Siebeck, 1990).

17 Webb, R, 307-348.
} 
be borne in mind that Pharisaic or early rabbinic teachers were disinclined to accept designation as prophets, and their attitude is embodied in classic stories concerning Chanina ben Dosa and Hillel. ${ }^{18}$ Similarly, Josephus refers to those who can predict the future; we naturally refer to such people as prophets, but Josephus calls them oracles (in Antiquities XIII $\S 313$ ), and in any case John is reputed in neither Josephus nor the New Testament for predictions of the future. Only the "popular prophet" among Webb's categories can claim some verbal affinity with Josephus, in that those who led groups into symbolic actions which the Romans interpreted as seditious are styled "false prophets."

Josephus' relative reserve in using prophetic designations is not unusual, when viewed in the context of rabbinic views and of the usage within 1 Maccabees 4:46; 9:27; 14:41; Psalm 74:9. Nonetheless, it is evident that Josephus, as we have seen, understood that prophetic functions continued to be exercised; the old generalization that "according to Josephus as well as the rabbis, prophecy ceased"19 is simply inadequate. By contrast, David Aune goes out of his way to insist that "Israelite prophecy did not disappear" in early Judaism. ${ }^{20}$ But in choosing to reverse Moore's judgment, instead of nuancing it, Aune creates a problem for himself: he finds cause to regret the "paltry evidence" for actual reference to prophets in early Judaism. ${ }^{21}$ The problem lies more in Aune's conception than in the inadequacy of the "evidence." The notion that prophecy simply ceased with Ezra is indeed simplistic, but the idea that canonization did not influence the practice of claiming directly prophetic authorization is unrealistic.

Webb follows in the wake of Aune's loose usage of the category of prophet, and argues that John was a Josephan "popular prophet," in that he baptized people in the Jordan:

\footnotetext{
18 See Berakhoth 34b and T. Sotah 13:3, discussed in Chilton, B, Profiles of a Rabbi: Synoptic Opportunities in Reading about Jesus (Brown Judaic Studies 177) (Atlanta: Scholars Press, 1989), 77-89.

19 So George Foot Moore, Judaism in the First Centuries of the Christian Era I (Cambridge: Harvard University Press, 1927), 240.

20 David Aune, Prophecy in Early Christianity and the Ancient Mediterranean World (Grand Rapids: Eerdmans, 1983), 103.

21 Aune, D, 189.
} 
Jesus' entry into Jerusalem and his occupation of the Temple, an enactment of the eschatological prophecy of Zechariah. ${ }^{25}$. When Jesus is called a prophet in that context (Matthew $21: 11,46$ ), it is arguable that there is some affinity with the sort of usage which Josephus presupposes (and implicitly rejects). There is, no doubt, a certain theological convenience in making John the symbolic rebel and Jesus the pacifist, but that typology is counter-factual.

If, as seems only reasonable, we remove the prophetic mantle from John, in that his garb appears more apologetic than historical, in what category are we to clothe him? Webb rightly insists that Josephus' testimony should be accorded privilege, but - as we have seen - his actual method (derived from David Hill's) is to press Josephus into the service of the apologetic tendency of the Gospels. ${ }^{26}$ For Josephus, John is not a false prophet, and he does not predict the future. Rather, he practices ablutions and preaches righteousness in the wilderness (Antiquities XVIII $§ 116-119$ ). Josephus does not provide John with a category, and in that regard his treatment invites comparison with the presentation of Bannus, the ascetic sage with whom Josephus claims to have lived and studied for three years (Life 10-12). Bannus is both wise and pure, and his frequent ablutions in cold water are a part of the pattern of his wisdom. That purity may also be associated with the purity of the Essenes Josephus describes as able to foretell the future.

But there are three, related features which distinguish John from Bannus within Josephus' presentation. First, a large following is attributed to John, while Bannus is a studiously solitary figure. Second, there is a self-consciously public dimension involved in John's preaching, which leads to his execution at the hands of Antipas. ${ }^{27}$ And third, John does not simply make ablution a personal practice, but urges the activity upon those who come to him. In a word, John makes baptism a public program, which both earns him his sobriquet and distinguishes him from Bannus.

The practice of frequent ablutions at Qumran has led to a comparison of John with the Essenes. That comparison has been somewhat complicated by the issue of whether the covenanters of Qumran and the Essenes are identifiable. A collation of Josephus,

\footnotetext{
${ }^{25}$ Cf Chilton, B, The Temple of Jesus: His Sacrificial Program within a Cultural History of Sacrifice (University Park: Pennsylvania State University Press, 1992), 91-111, 113-136.

26 David Hill, New Testament Prophecy (London: Marshall, Morgan \& Scott, 1979), 43-47.

${ }^{27}$ Cf Harold W Hoehner, Herod Antipas (Grand Rapids: Zondervan, 1980, 110-171.
} 
Gentiles, but anyone not of their vision (see The Manual of Discipline and The War of the Sons of Light and the Sons of Darkness). The culmination of those efforts was to involve complete control of Jerusalem and the Temple, where worship would be offered according to their revelation, the correct understanding of the law of Moses (cf Zadokite Document 5:17-6:11). Their insistence upon a doctrine of two messiahs, one of Israel and one of Aaron, would suggest that it was particularly the Hasmoneans' arrogation of priestly and royal powers which alienated the Essenes, and such a usurpation of what the Essenes considered divine prerogatives also characterized Herodian settlements with Rome.

On a routine level, the Essenes appear to have focused on the issue of purity, thus maintaining a tense relationship with the cultic establishment which comported well with their apocalyptic expectation that control of the Temple would one day be theirs. Some of them lived in cities, where they performed ablutions, maintained distinctive dietary regulations, observed stricter controls on marital relations than was common, and regulated the offerings they brought to the Temple according to their own constructions of purity. A more extreme form of the movement lived apart from cities in communities such as Qumran: in them celibacy and a break with ordinary, sacrificial worship was the rule. The aim throughout, however, was the eventual governance of the Temple by Essene priests, the first phase of the war of the sons of light against the sons of darkness.

The practice of regular ablutions at Qumran shows that Bannus, John the Baptist, and the Pharisees were in no sense unique, or even unusual, in their insistence upon such practices. But the entire direction of Essene practice, the interest in the actual control of worship in the Temple, appears unlike John's. The notion that John somehow opposed the cult in the Temple is weakly based. The argument is sometimes mounted that, because John preached a baptism of repentance for the forgiveness of sins, he consciously challenged the efficacy of sacrificial forgiveness. ${ }^{32}$ Such assertions invoke a supposed dualism between moral and cultic atonement which simply has no place in the critical discussion of early Judaism, and they in no way suffice to establish that John deliberately opposed worship in the Temple. The motif of his preaching "a baptism of repentance for

32 Webb, R, 192-3 and Joseph Thomas, Le mouvement baptiste en Palestine et Syrie (150 av. J C -- 300 ap. JC) (Gembloux: Duculot, 1935). 
Philo, Pliny and the scrolls nonetheless results in a reasonably coherent picture, which has been masterfully represented by Todd $\mathrm{H}$ Beall. ${ }^{28}$ Robert $\mathrm{H}$ Eisenman, on the other hand, stresses that Pliny was writing in the period after the revolt in Natural History 5.15 $\S 70-73$ when he described Essenes as living on the western shore of the Dead Sea with Engedi below them. ${ }^{29}$ His contention is that the community of the scrolls centered on James (Jesus' brother) as the righteous teacher. But his speculative reading of Pliny must also confront an anachronism: Qumran was destroyed by the Romans in $\mathrm{AD} 68 .^{30}$ Whoever Pliny described was living in conditions ill suited for habitation, or at some site other than Qumran, or in fact dwelled there at an earlier period. In that Pliny appears to be referring to a site which had not been destroyed and Qumran suits the location as described, the most plausible explanation is that he is describing an earlier setting on the basis of his authorities (a list of which he provides in book one). And the earlier setting, of course, would not allow time for a sect to have emerged which venerated the dead James. In addition, Eisenman's theory must impute to James views which there is no record that he held, and posit a hermetic separation between his movement and early Christianity which the continued memory of James within the Church makes improbable. Finally, he must also suppose that the deposit of the scrolls in the caves nearby had nothing whatever to do with the history of earlier habitation at Qumran. It is not at all clear that the theory explains anything sufficiently important to compensate for the obscurity it generates.

The Essene movement appears to have its origins in opposition to the Hasmoneans. The Essenes pursued their own system of purity, ethics, and initiation, followed their own calendar, and withdrew into their own communities, either within cities or in isolated sites such as Qumran. ${ }^{31}$ There they awaited a coming, apocalyptic war, when they, as "the sons of light," would triumph over "the sons of darkness:" not only the

\footnotetext{
${ }^{28}$ Todd S Beall, Josephus' description of the Essenes illustrated by the Dead Sea Scrolls (Society of New Testament Studies Monograph Series 58) (Cambridge: Cambridge University Press, 1988).

${ }^{29}$ Robert H Eisenman, James the Just in the Habakkuk Pesher (Studia Post-Biblica) (Leiden: Brill, 1986), 83-4.

${ }^{30}$ Roland de Vaux, Archaeology and the Dead Sea Scrolls (London: Oxford University Press, 1973), 1-45.

${ }^{31}$ David Flusser, "The Social Message from Qumran," Judaism and the Origins of Christianity (Jerusalem: Magnes, 1988) 193-201.
} 
People would leave their homes in Jerusalem/Judea, where they experienced a sense of oppression and deprivation, perhaps reminiscent of what their ancestors experienced in Egypt. They would travel through the wilderness to the Jordan river following the call of the prophet John, again reminiscent of the people of Israel traveling through the wilderness under the leadership of a great prophetic figure, Moses. They would come to the Jordan river and enter it (possibly crossing to the other side), reminding them of the other "crossings": the Red Sea and the Jordan river in the Exodus and Conquest. Here they were baptized by John with a repentance-baptism which functioned to initiate them into the group of prepared people, the true Israel. As such, they expected imminently the restoring ministry of God's agent who would make them a holy group and remove the wicked from their midst ...22

Webb must admit, however, that John's ministry was by no means limited to the river itself $^{23}$ and that, unlike the false prophets, John did not engage in a single, dramatic symbol of liberation. ${ }^{24}$ But his admission does scant justice to the clear indications that the reference to the Jordan in Matthew 3:6; Mark 1:5 is not to be taken as a limitation: the specific word "river" is omitted in significant witnesses, and the Lukan analogue (3:3) is a purely regional reference. Moreover, the baptist is explicitly portrayed as baptizing at other sites in John's Gospel (Bethany in 1:28, Aenon in 3:23); and although his setting is Judaean, the Jordan river is not mentioned as a place where people are baptized. Within the Fourth Gospel, the Jordan is more a point of reference $(1: 28 ; 3: 26$, cf $10: 40)$ than a place where action unfolds.

In any case, the symbolism of bathing is not transparently revolutionary. It can scarcely be compared with what Josephus said the false prophets did: one scaled Mount Gerizim to find the vessels deposited by Moses (Antiquities XVIII $\S 85-87$ ), Theudas waited at the Jordan for the waters to part (Antiquities XX $\S 97,98$ ), the Egyptian marched from the Mount of Olives so that he might conquer Jerusalem (Jewish War II $\S$ 261-63). If there is an act in the Gospels which approximates to such fanaticism, it is

\footnotetext{
${ }^{22}$ Webb, R, 364.

${ }^{23}$ Webb, R, 363 n 27. Cf Scobie, H H, 41-48.

${ }^{24}$ Webb, R, 265.
} 
the release of sins" may in any case represent the anachronistic assignment to John of an element of the language of catechesis within early Christianity. The phrase appears in Mark 1:4; Luke 3:3 (cf 1:77) in relation to John, but "for release of sins" appears in manifestly Christian contexts at Matthew 26:28; Luke 24:47. Webb can see the problem posed for his thesis by such passages as Acts $2: 38$, and his only defense is a methodological bias against any "skeptical conclusion." 33 Josephus more accurately observed that John's baptism was not understood to seek pardon for sins, but to purify the body (Antiquities XVIII § 117).

The motif of John's priesthood is similarly beside the point of any alleged antagonism to worship in the Temple. ${ }^{34}$ The fact of being born a priest did not necessarily involve anyone in the service of the Temple on a regular basis although it might conceivably have prompted the increased concern with purity which evidently characterized John. Even so, the fact that he was a priest did not imbue Josephus with a marked sensitivity to the issue. He had no scruples regarding where Jews in Syria were to buy their oil (cf Jewish War II § 590-594), and expressed none in regard to fighting on the sabbath or dealing with the uncleanness occasioned by corpses. He mentions Herod's installation of the golden eagle in the Temple only when certain (apparently Pharisaic) rabbis object to it, and ventures no vigorous opinion of his own (Jewish War I § 648650 ). The only time he refers categorically to the impurity of food, an issue which must have plagued many military campaigns during the period, is in order to assail the impiety of John of Gischala at the end of the war (Jewish War VII § 264).

Some priests, especially among the privileged families in Jerusalem, were notoriously pro-Roman. The story of sons of the high priest having the surgery called epispasm, in order to restore the appearance of a foreskin (for gymnastic purposes) is well known (cf 1 Maccabees 1:14, 15; Antiquities XII $\S 240,241$ ). There is little doubt but that such families, the most prominent of which were the Sadducees and Boethusians, were not highly regarded by most Jews (cf b Pesachim 57a). They are typically portrayed in a negative light, as not teaching the resurrection of the dead (cf Jewish War II $\S 165$; Matthew 22:23; Mark 12:18; Luke 20:27; Acts 23:8), but the issue may have been one of

\footnotetext{
${ }^{33}$ Webb, R, 171.

34 Cf Webb, R, 193.
} 
emphasis: the Torah had stressed that correct worship in the Temple would bring with it material prosperity, and the elite priests attempted to realize that promise. The arrangement gave them such consistent control that they became known as "high priests," although there was in fact only one high priest. But Josephus indulges in the usage, as well as the Gospels, so that it should not be taken as an inaccuracy: the plural is a cultic mistake, but marks a sociological fact.

Members of most priestly families were not "high priests," and did not in any sense exercise control over the Temple, or even participate ordinarily in the conduct of worship there. The well known courses of 1 Chronicles 23; 24; Ezra 2:36-39; 10:18-22; Nehemiah 10:3-9; 12:1-7, 12-21; Antiquities VII § 365, 366; Life 2; Against Apion 2 \$108 provided for only occasional service (cf Luke 1:8,9). Within the Gospels, priests appear locally, in adjudications of purity (Matthew 8:1-4; Mark 1:40-45; Luke 5:12-16 cf Luke $10: 31 ; 17: 14$, and the exceptional role of Zechariah in 1:5-23), while high priests are essentially limited to Jerusalem, or use Jerusalem as a base of power (cf Matthew 2:4; $16: 21 ; 20: 18 ; 21: 15,23,45 ; 26: 1-28: 11$; Mark 8:31; 10:33; 11:18, 27; 14:1-15:31; Luke $3: 2 ; 9: 22: 19: 47 ; 20: 1-24: 20 ;$ John 1:19; 7:32, 45; 11:47, 49, 51, 57; 12:10; 18:3-19:21). Several priests were also prominent in the revolt against Rome, however, and it should not be thought that such priestly nationalists, among whom were Joseph bar Matthias, better known as Flavius Josephus, emerged only during the latter half of the sixties (Jewish War II $\S 562-568$ ). The precedent of the Hasmoneans was there for any priestly family to see as a possible alternative to Roman rule, direct or indirect. Indeed, some priests were not only nationalists, but revolutionaries, who joined with the Essenes, or with rebellious Pharisees, although any alliance with a prophetic pretender is, perhaps, not a likely supposition. In any case, John well may not have been a priest: the claim that he was is weakly attested (Luke 1:5), and made within the same complex of material which asserts that Jesus was related to him (cf Luke 1:36), although of Davidic ancestry (cf 1:27 and 1:69). The line which divides historical reminiscence from theological typology is particularly difficult to draw here.

Once it is appreciated that John is not known to have shared the cultic program of the Essenes, the argument that he is to be associated with the covenanters of Qumran loses its foundation. W H Brownlee gave currency to the view that the usage of Isaiah 40 
in The Manual of Discipline viii.14; ix.19 shows that "John must have been familiar with Essene thoughts regarding the coming of the Messianic age." ${ }^{35}$ More accurately, one might say that the analogy suggests that Isaiah 40 was known both to the covenanters and to the Christians who revered John's memory as their master's forerunner. To build upon such analogies and Luke 1:80 the speculation that John was orphaned and raised by the Essenes is an exercise in hagiography.

Essene practice, together with Pharisaic, Sadducean, and Bannus' practice, does suggest by analogy a likely feature of John's baptism which contemporary discussion has obscured. It is routinely claimed that John preached a "conversionary repentance" by baptism, an act once for all which was not repeatable nor to be repeated. ${ }^{36}$ That is a fine description of how baptism as portrayed in the Epistle to the Hebrews 6:1-8, and such a theology came to predominate within catholic Christianity. But ablutions in Judaism were characteristically repeatable, and even Hebrews must argue against the proposition that one might be baptized afresh. Only the attribution to John of a later, catholic theology of baptism can justify the characterization of his baptism as symbol of a definitive, unrepeatable "conversion."

If John's baptism was not in the interests of "conversion," or permanent purification, or upposition to atonement by means of cultic sacrifice, what was its purpose? Josephus in Antiquities XVIII $\S 177$ asserts that John's baptism was to serve as a ritual of purity following a return to righteousness. Righteousness and bathing together made one pure. Josephus makes a nearly or actually dualistic distinction between the righteousness which effects purification of the soul and the baptism which symbolizes the consequent purification of the body, and that is consistent with his portrayal of others with whom he expresses sympathy, the Essenes, the Pharisees, and Bannus.

Webb argues, following Steinmann, that John attempted to found a sect after the manner of the Essenes. ${ }^{37}$ The thesis founders on several considerations. There is no evidence whatever that baptism for John constituted an initiation, comparable to the

\footnotetext{
${ }^{35}$ W H Brown, "John the Baptist in the New Light of Ancient Scrolls," Interpretation 9 (1955) 71-90, 73; cf Steinmann, J, 59.

${ }^{36}$ Webb, R, 197-202.

37 Webb, R, 197-202; Steinmann, J, 5.
} 
ceremony for novices at Qumran. ${ }^{38}$ It is not even to be assumed - as we have seen - that baptism for John was not to be repeated. Moreover, no discipline but "righteousness" was required by John, as far as the available evidence would suggest. His execution was not occasioned by placing any unusual requirement upon Antipas, but for insisting Antipas keep the Torah of purity as any person might understand it, by abstaining from marrying his brothers wife (cf Leviticus 20:21; Matthew 14:3-4; Mark 6:17-18; Luke $3: 19)$.

The purpose of John's baptism must be sought, not in an unfounded hypothesis of sectarian motivations or in the apologetic presentation of the Synoptics, but in the nature of his activity as compared to ordinary practices of purification. It is just here that contemporary students of John have been most misled by the supposition that he was a prophet with a recoverable message which explains his activity. Historically, his activity is itself as much of his program as we are ever likely to grasp.

John practiced his baptism in natural sources of water. It is sometimes taken that his purpose was to use literally moving water, but that it not specified in any source, and the waters of the Jordan or a pool in Peraea or an oasis in the valley of the Jordan would not necessarily be flowing. Indeed, Sanders has reminded us that water from a spring was equated with the category of naturally collected water by the first century. ${ }^{39}$ Moreover, even if John did use living water by preference, the especial corruption of what was thereby purified was not thereby marked, as is sometimes supposed $:^{40}$ corpse contamination, after all, was dealt with by means of the still water of the ashes of the red heifer, not living water (cf Numbers 19 and Parah 5:1-8:11). John's baptism made no statement as to the nature of what was to be purified: his activity took that as being as self-evident as Antipas' lapse. John's baptism was, however, an implicit claim that there was no advantage in the pools of Qumran, the double vatted miqvaoth of the Pharisees, or the private baths of aristocratic groups such as the Sadducees. ${ }^{41}$ He enacted what amounted to generic purification, in contrast to the deliberate artifice involved in several other

\footnotetext{
38 See Flusser, D, 109.

39 Jewish Law from Jesus to the Mishnah (Philadelphia: Trinity Press International, 1990), 215.

40 Webb, R, 193.

${ }^{41}$ See Sanders, E P, Jewish Law 214-227.
} 
movements, sectarian and non-sectarian. In that sense, his purpose was deliberately antisectarian.

Inferentially, it might be maintained that John's baptism was driven by an eschatological expectation, not necessarily of a messiah, but of divine judgment. ${ }^{42}$ of all the statements attributed to John, the claim that after him a baptism of spirit was to come stands out as possibly authentic. Whether or not it is, the anticipation of imminent judgment would both supply a suitable motivation for John's activity and help to account for his appropriation within early Christianity. But whatever his own motivation, and those of subsequent interpreters, that he acted as a purifier on the basis of ritual bathing is the most certain - as well as the most obvious - feature of his public activity.

\section{THE CHRONOLOGY OF JOHN'S DEATH}

Josephus' famous report about John in Antiquities $18 \S 116-119$ is a flashback, related to explain the opinion among "some Jews" that the defeat of Antipas' army at the hands of Aretas, the king of Nabatea, was divine retribution for his treatment of John. What Josephus does not say, but the Gospels do attest (Mark 6:18-29; Matthew 14:3-12; Luke 3:19-20), is that John had criticized Antipas for marrying Herodias, who had been married to his brother Philip. Josephus' account dovetails with the Gospels, ${ }^{43}$ in that he gives the details of Antipas abortive divorce from Aretas' daughter in order to marry Herodias ( $\$ 109-112) .^{44}$ But Josephus also explains that this was merely the initial source of the enmity, which was later exacerbated by a border dispute that preceded the outbreak of hostilities ( $§ 113)$.

In fact, he says that Aretas "made this the start of a quarrel," as if it were something of a self-justification in retrospect. No delay of time is indicated in the compressed narrative between the divorce and John's death and the start of the war, but mounting tension is indicated. It is also noteworthy that Josephus blames the defeat on the betrayal

\footnotetext{
42 So Flusser, D, "The magnificat, the Benedictus, and the War Scroll," Judaism and the Origins of Christianity, 126-149, 148.

${ }^{43}$ So Robert L Webb, Studying the Historical Jesus: Evaluations of the State of Current Research (New Testament Tools and Studies 19) (eds B Chilton and C A Evans; Leiden: Brill, 1994) 179-229, 209.

${ }^{44}$ It may be an important hint that Antipas planned to divorce his wife after his return from a visit to Rome $(\S 110)$.
} 
by some of Philip's troops, who had joined his army $(\S 114)$. So: the delay is long enough for tension to have mounted with Aretas, and for Antipas - however unwisely to believe that his brother's troops would loyally fight for him. ${ }^{45}$ Philip died in 34 (see $\S$ 106), and this defeat is usually placed c. 36. The death of Philip would have provided ample motivation for the soldiers to join Antipas, and a delay of some fifteen years from the divorce would perhaps account for Antipas' acceptance of their services.

It has been suggested that John died as late as $32 \mathrm{CE},{ }^{46}$ but that seems not to fit the case, or any accepted chronology of Jesus' life. Indeed, the late dating of John's death has caused Joan Taylor to imagine a radically revised chronology of Jesus' death: John may have been killed as late as 33 or early in 34 . For all we know, Jesus' death may have followed quite soon after, or as late as $36 .^{47}$ That view comes, however, of accepting Josephus' association of the death of John with the tenure of Vitellius, when Josephus himself introduces the material about John as a flashback. That analeptic technique is as natural to Josephus as compressed narration is in the Gospels. Account of both needs to be taken in establishing the time of John's death, which therefore need not be placed immediately before Antipas' defeat, nor near the time of Jesus' execution. F F Bruce long ago warned about pressing Josephus' presentation literally:

It may well be, as Josephus says, that some of Antipas's subjects saw in this defeat the divine nemesis for Antipas's execution of John the Baptist; but it is unimaginative to conclude that John's execution must therefore have been much more recent than the Evangelists indicate. The Pharisees and many other Jews believed that the mills of God ground slowly; if divine nemesis could wait fifteen years before Pompey for violating the sanctity of the holies of holies in Jerusalem [here Bruce notes Psalms of Solomon 2:30f.), it is not

\footnotetext{
${ }^{45}$ Commentators routinely argued that the Philip involved was not the tetrach, but another brother; see, for example, Alfred Durand, Évangilee salon Saint Matthew (Verbum Salutis) (Paris: Beauchesne, 1948) 274275. The behavior of the troops (and of Antipas) as described by Josephus supports the Gospels' identification.

46 See B Witherington, "John the Baptist," Dictionary of Jesus and the Gospels (eds J B Green and S McKnight; Dover Grove: InverVarsity, 1992) 383-391, 388.

47 Joan E Taylor, The Immerser, 255-258.
} 
extraordinary that it would have waited a mere seven years before taking vengeance for the death of John. ${ }^{48}$

What I find interesting about this disagreement is that, in their opposition over whether to take the notice of time in Luke 3:1-3 as accurate, the lines of discussion represented by Taylor and Bruce nonetheless accept it as the terminus post quem. That seems to me odd, because that same reference to the fifteen year of Tiberius is also taken as the standard point of departure for Jesus' public activity. Luke is evidently compressing, and the compression extends to conflating John and Jesus. What if we were to entertain the possibility of a Josephan chronology for John, and dispense with the Synoptic chronology?

Bruce actually opens this line of investigation early in his discussion, with his remark that Antipas would have sought to divorce Aretas' daughter "after living with her twenty years or more." "Or more" is an understatement, because the marriage with her was presumably undertaken shortly after the Nabatean involvement in violence following the death of Herod the Great, as part of Antipas' attempt to solidify his position. On Bruce's chronology, the marriage would have been nearly thirty years old by the time Antipas decided to divorce the daughter of Aretas.

Whenever Antipas made his decision, it was a bold move. It involved him in breaking with Aretas, and it inflamed Jewish opinion, bring not only John's censure, but even that of Josephus (Antiquities $18 \S 110$ ). Nor was there any mystery about the likely Jewish reaction against the marriage; after all, Archelaus had nu afoul of popular opinion when he married the wife of a dead brother (Antiquities $17 \S 340-341$ ). Antipas is usually credited with more sensitivity than that to the demands of the Torah, and it is doubtful he acted out of simple passion. Still, it was a rash act, and to this extent the recent suggestion by Christiane Saulnier that the divorce and the new marriage were over and done with by the early twenties is plausible. ${ }^{50}$

\footnotetext{
${ }^{48}$ F F Bruce, New Testament History (Garden City: Doubleday, 1972) 30-31.

49 Bruce, F F, p 28.

so See "Herode Antipas et Jean le Baptiste. Quelques remarques sur les confusions chronologiques de Flavius Josèphe," Revue Biblique 91 (1984) 362-376.
} 
Saulnier proceeds on the basis that Josephus is better informed chronologically about Agrippa I than about another other Herodian hence: ${ }^{5 i}$

\begin{abstract}
Ce récit laisse entendre que Hérode Antipas et Hérodiade étaient déjà officiellement mariés au moment du retour d'Hérode Agrippa, c'est-à-dire au printemps 24 , et implique que le séjour du tétrarque à Rome était antérieur d'un ou deux ans au moins. Cette date présente l'avantage de ne pas être en desaccord avec la tradition évangélique, néanmoins le visite d'Hérode Antipas à la cour impériale entre 21 et 23 est-elle vraisemblable?
\end{abstract}

She finds that it is not difficult to imagine Antipas visiting Rome between 21 and 23, and associates that visit with a supposed intervention on behalf of Roman Jews who had been exiled to Sardinia (Antiquities $18 \S 81-84$ ). ${ }^{52}$ I personally do not see that Antipas had the influence or the inclination to help Jews in Rome, so I identify other reasons for the visit below. That change causes me to place the marriage with Herodias slightly earlier than Saulnier suggests, although my proposal is in line with her proposal as a whole. I also depart from other aspects of Saulnier's chronology, which still tries too hard in my view to vindicate the presentation in the Synoptics, but it is still well worth considering: ${ }^{53}$

Hérode Antipas et Hérodiade se sont mariés au plus tard en 23; Jean le Baptiste a été exécuté en 27 ou 28 et il est plausible qu'il ait publiquement critiqué cette union. A la suite de l'affront fait à sa fille, Arétas a vaincu l'armée du tétrarque vers 29. Hérode Antipas s'est trouvé à Jérusalem avec Vitellius au printemps 37 , après le renvoi de Ponce Pilate; la même année il a participé aux négociations menées avec les Parthes mais, par sa maladresse, s'est attiré l'inimitié du légat. En outre il s'était brouillé avec Hérode Agrippa, alors qu'il séjournait à Rome en 21 our 22 pour intercéder en faveur des Juifs déportés en Sardaigne. En 39, son nevue l'avait accusé d'avoir comploté avec Séjan avant 23 et d'être entré en communsin avec les Parthes

\footnotetext{
\$I Saulnier, C, pp 365-366.

52 Saulnier, C, pp 367-368.

$\$ 3$ Saulnier, C, pp 375-376.
} 
en 36 our 37; le crédit, dont jouissait Hérode Antipas auprès de Caligula, avait failt accepter ces charges, justifiant la déchéance et l'exil du tétrarque.

A reading of Josephus with due account of his narrative technique largely supports Saulnier, and permits a somewhat more specific dating. Prior to dealing with Vitellius (from Antiquities $18 \S 88$ ), and therefore flashing back to Antipas' various trials, Josephus has last spoken of Antipas in connection with the establishment of Tiberias in $19 \mathrm{CE}$ (Antiquities $18 \S 36-38$ ). Here, too, Josephus criticizes Antipas, because the city was partially established on the site of tombs, and he complains elsewhere that the palace there incorporated idolatrous representations of animals, which Josephus himself undertook to destroy (Life 64-69). Why, then, do we see Antipas in such an uncharacteristically trenchant philo-Roman mode, flouting commandments of the Torah in a way which could only have alienated his subjects?

At the opening of his section on Tiberias, Josephus provides an answer: Antipas had advanced considerably within the circle of Tiberius' friendship (Antiquities $18 \S 36$ ). Having been educated in Rome, his contacts with the city were no doubt good, but it is unlikely that this advance was accomplished without an actual visit. Was this the visit Josephus refers to in connection with Herodias in Antiquities $18 \S 110-111)$ ?

There is good reason to think so. After all, his tenure came to an abrupt end when, prodded by Herodias, Antipas made the trip to Rome in 39 CE to plea for the title of king (Antiquities $18 \S 240-256$ ). Indeed, Gaius is said to have personally exiled her along with her husband for her ambition. Josephus opines that exile served Antipas right for his attention to the nattering of his wife. But her ploy was consistent with her marriage in the first place, and with the foundation of Tiberias, as part of a policy of establishing Antipas as a Herodian king on a good footing in Rome. She underestimated the cunning of Herod Agrippa, her own brother, but her influence was part of a strategic desire. That same desire had worked earlier, when her husband had returned from Rome to marry her, and the no doubt happy couple were ensconced in Tiberias. At that time, it 
only remained to see to the death of John (around $21 \mathrm{CE}$, contrary to the Synoptic chronology and Saulnier ${ }^{54}$ ) to make her happiness complete.

\section{CONCLUSION}

John's status as a prophet derives from the tradition of Christian apologetics (indeed, from Jesus himself, to judge from Matthew 11:9; Luke 7:26), but his activity and program within the terms of reference of Judaism made him a purifier. He was certainly not a routine figure, because his take on purity was both distinctive and controversial, but Josephus shows us that John cut a recognizable profile as a practitioner and teacher.

A reading of Josephus also suggests that John need no longer be dated within the Synoptic chronology, whose usage as a catechetical instrument makes it an unreliable historical tool. Rather, John was put to death well before Jesus came to adulthood (perhaps in $21 \mathrm{CE}$ ), during a period when Herod Antipas was emboldened by his recent foundation of Tiberias as well as his marriage to the ever ambitious Herodias, once his brother's wife. That suggests that John affected Jesus more deeply than a passing visit from Galilee to Judea for baptism (Matthew 3:13-17; Mark 1:9-11) would indicate. Jesus would have known John during his adolescence, and the purifier's persepective on cleanness and related matters proved to be a formative influence. ${ }^{55}$

\footnotetext{
s4 My other departures from her dating all derive from the decision to infer the chronology from Josephus alone.

55 Cf Chilton, B, "The Talmid of John," in Rabbi Jesus: An Intimate Biography (New York: Doubleday, 2000) 41-63.
} 